\title{
Menakar Kesyariahan Fintech Syariah di Indonesia
}

\author{
Fathul Aminudin Aziz \\ Fakultas Ekonomi dan Bisnis Islam IAIN Purwokerto \\ Jl. A. Yani No. 40A Purwokerto 53126 Banymas Jawa Tengah \\ Email:fathulaminudinaziz@iainpurwokerto.ac.id
}

\begin{tabular}{llll}
\hline Submit & $:$ 30 Januari 2020 & Diterima & $:$ 18 Mei 2020 \\
Revisi & $: 03$ April 2020 & Terbit & $:$ 03 Juni 2020 \\
\hline
\end{tabular}

\begin{abstract}
Abstrak: Perkembangan teknologi informasi merambah masuk ke semua sektor keuangan, termasuk ke financial technology (fintech) syariah. OJK sebagai regulator industri keuangan telah mengeluarkan peraturan, untuk mengantisipasi perkembangan dan pemanfaatan IT dalam industri keuangan seperti lending, personal finance, crowd funding, uang elektonik, investasi ritail, payment gateway, wealth management dan berbagai startup lainya. Literasi Syariah perlu ditingkatkan dengan jalan memeberikan pemahaman bahwa syariah adalah label dan hakikat, teori dan praktek, maka kehalalan diukur dari seberapa banyak unsur kesyariahan terpenuhi. Adapun unsur-unsur fintech syariah di Indonesia antara lain adalah, akuntabilitas, transparasi informasi, kewajaran, kesetaraan, kesalehan sosial, terhindar dari transaksi yang ribawi, maysir, gharar, risywah, tadlis, dan israf, serta dijamin kehalalannya. Jadi sesungguhnya kesyariahan itu memiliki takaran yang berbeda-beda tergantung seberapa besar terpenuhi unsur syari'nya. Semakin besar takaran kehalalan terpenehuhi maka semakin besar pula kehalalanya, begitu juga sebaliknya semakin kecil unsur kehalalan terpenuhi maka semakin kecil pula nilai kehalalan transaksi fintech nya.
\end{abstract}

Kata kunci: fintech, syariah, menakar, OJK, Indonesia.

Abstract: The development of information technology penetrated into all financial sectors, including sharia financial technology (Fintech). OJK as a regulator of the financial industry has issued regulations, to anticipate the development and utilization of IT in the financial industry such as lending, personal finance, crowdfunding, electronic money, investment investments, payment gateways, wealth management and various other startups. Shari'ah literacy needs to be improved by giving an understanding that shari'ah is label and nature, theory and practice, so halal is measured by how many elements of sharia are fulfilled. As for the elements of Islamic fintech in Indonesia, among others, accountability, transparency of information, fairness, equality, social piety, avoidance of transactions that are reckless, maysir, gharar, risywah, tadlis, israf, and halal. different amounts depending on how much the shari'a element is fulfilled. The greater the halal dose is fulfilled, the greater the halal, and vice versa the smaller the halal element is fulfilled, the smaller the halal value of its fintech transactions.

Keywords: fintech, Shariah, assessment, OJK, Indonesia 


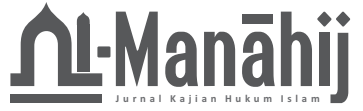

\section{Pendahuluaan}

Perkembangan teknologi semakin cepat semakin menantang. Kali ini giliran pasar keuangan perbankan harus bersiap diri. Kini mulai banyak penyedia jasa keuangan yang menggunakan teknologi mengelola dana, ataupun juga menyalurkan dana via akun tertentu di dunia maya. Financial technology atau fintech adalah penggunaan teknologi untuk memberikan solusi keuangan. ${ }^{1}$ Begitu juga dengan teknologi dan internet memiliki peranan sangat penting dalam setiap aktifitas kehidupan umat manusia saat ini. Dengan jumlah masyarakat Indonesia yang sangat besar memiliki pengaruh besar terhadap perilaku masyarakat dan pemanfaatan bisnis keuangan berupa e-commerce/online dalam bentuk financial technology (fintech). ${ }^{2}$ Fintech didefinisikan sebagai salah satu bisnis berbasis software dan teknologi yang menyediakan jasa keuangan modern. Fintech memiliki tujuan untuk meningkatkan inklusi keuangan, mempermudah dalam mengakses beberapa produk keuangan yang dikehendaki masyarakat dan mempermudah transaksi. Pada umumnya Fintech di Indonesia memiliki potensi yang sangat besar karena dapat memberi solusi untuk kebutuhan mendesak yang tidak dapat diberikan oleh lembaga keuangan tradisional.

Fintech merupakan gelombang baru yang memberikan model baru dalam cara individu dalam bertransaksi, seperti membayar, mengirim uang, meminjam, meminjamkan dan menginvestasikan uang. ${ }^{3}$ Sederhananya fintech mengawinkan antara teknologi dengan keuangan, baik itu perbankan atau pun yang lainnya. Dengan dibentuknya sebuah sistem ini yang lebih cepat, lebih efisien apalagi di tengah masyarakat yang menggunakan teknologi dengan sangat pesat, dengan dilatarbelakangi oleh krisis dalam bidang ekonomi yang terjadi pada tahun 2008.

Ragam fokus teknologi finansial, mayoritas yang bergerak di bidang ini adalah para start up yang merupakan salah satu pioneer sehingga menciptakan sesuatu yang baru untuk masyarakat yang tidak lagi menggantungkan kepada sistem konvensional. Bisnis startup adalah suatu usaha rintisan yang berada pada tahap pengembangan dan disertai dengan adanya riset pasar. ${ }^{4}$ Inovasi dalam bisnis startup terjadi apabila pengusaha dapat menciptakan sebuah inovasi teknologi serta menjadikan produk tersebut dipasarkan sehingga mendatangkan keuntungan. ${ }^{5}$ Salah satu contoh konkritnya adalah peminjaman dalam perbankan yang dapat dilakukan beberapa hari, akan tetapi dengan fintech yang kini sudah banyak dan menjamur di akun-akun dunia maya lebih singkat lagi prosesnya. Apa lagi dengan salah satu atau beberapa investor yang menyediakan dana untuk masyarakat yang membutuhkan maka hal ini sangat bermanfaat salah satunya Usaha Kecil dan Menengah. Hal ini dikarenakan waktu yang dibutuhkan lebih cepat, efisien dan memangkas biaya-biaya yang tidak diperlukan sehingga banyak perusahaan start up di bidang fintech yang masuk di platform peminjaman.

Selanjutnya adalah alat pembayaran. Pemerintah Indonesia sudah mulai mensosialisasikan bagaimana cashless bisa masuk ke masyarakat. Masyarakat tidak perlu lagi membawa uang tunai, untuk membayar sebuah transaksi, melainkan dapat dilakukan dengan kartu debet atapun dengan kartu kredit, bahkan sekarang sudah ada e-money ketika kita masuk ke tol. Alat pembayaran akan

D Aaker, Building Strong Brands (Jakarta: Bumi Aksara, 2014).

I Romanova and M Kudinska, Contemporarry Issues in Finance : Banking and FinTech : A Challenge or Opportunity? (London: Emerald group Publishing Limited, 2016).

3 Fitri Amalia, 'Book Review: The Fintech Book: The Financial Technology Handbook for Investor, Enterpreneurs and Visionaries', Journal of Indonesia Economic and Business, Volume 31 (2016), 346.

4 Marina Klackmer Calopa, Jelena Horvat, and Maja Lalic, 'Analysis of Financing Sources For Start-Up Companies', Management Journal, Volume 19 (2014), 19-44.

Wincent Drnovsek and Cardon, 'The Nature and Experience of Enterpreneurial Passion', 2010, 56. 
semakin mudah ketika ada fintech di dalamnya. Penggunaan e-money saat ini merupakan alternatif alat pembayaran non-tunai, namun di sisi lain e-money juga memiliki berbagai potensi risiko yang akan muncul setelah terjadinya transaksi. ${ }^{6}$

Fokus selanjutnya adalah peer to peer. Peer to peer lending (P2P) merupakan fintech yang mempertemukan antara pemberi pinjaman (investor) dengan para pencari pinjaman dalam satu platform. Nantinya para investor akan mendapatkan bunga dari dana yang dipinjamkan. Perbandingan layanan bank dan asuransi menarik ketika situs-situs yang ada saat ini dapat kita masuki untuk dijadikan perbandingan antara berbagai bank atau penyedia jasa keuangan yang ada, salah satunya yaitu berapa jumlah total pinjaman yang dapat dilakukan, administrasi dan bunga bank. Terdapat simulator di dalamnya sehingga akan lebih mudah ketika kita akan meenetukan pilihan akan menggunakan jasa perusahaan mana yang akan kita pilih untuk berinvestasi maupun melakukan transaksi pinjaman.

Saat ini hampir setiap orang menikmati dan menggunakan fintech, artinya perkembangan yang begitu cepat mampu merubah tatanan perekonomian dunia. Dari mulai klasikal menuju ke modern. Sudah tak dapat dipungkiri lagi, karena semua sudah memasuki zamannya. Produk-produk yang dihadirkan oleh perusahaan fintech saat ini hampir menyerupai prodak perbankan dan lembaga keuangan lainnya akan tetapi hasilnya lebih efisien. Oleh karena itu, banyak produknya yang beririsan dengan komoditas berbagai lembaga keuangan konvensional. Industri yang sangat cepat berkembangnya ini karena ditopang dengan teknologi yang canggih sehingga aspek hokum fintech tidak lagi relevan dengan berbagai regulasi yang ada.

Celah aturan yang belum lengkap dan tegas sangsinya berdampak pada banyaknya oknum yang memanfaatkan kecanggihan teknologi dengan cara melakukan kejahatan, salah satu kasus yang ada dalam perusahaan fintech adalah pinjaman illegal dimana pinjaman yang diliarkan oleh entitas tidak punya izin yang sah oleh OJK. Perlu kita ketahui terkait lembaga jasa keuangan mana saja yang memiliki izin dari OJK. Ciri lembaga jasa keuangan yang memiliki indikasi ilegal, ${ }^{7}$ pertama, tidak ada lambang OJK di website atau aplikasi pinjaman online. Kedua, aplikasi pinjaman online ilegal tidak terdaftar di Google Play Store. Ketiga, tingkat bunga, biaya dan denda sangat tinggi. Meskipun proses pencairan sangat cepat dan mudah, namun fintech ilegal menerapkan bunga, denda dan biaya yang sangat mencekik nasabah. Keempat, alamat kantor dan call center pinjaman ilegal tidak jelas atau bahkan tidak ada. Kelima, perlu waspada jika proses pengajuan pinjaman sangat mudah, termasuk di dalamnya dengan menggunakan label syariah.

Bank Indonesia mendorong pengembangan fintech berbasis syariah karena dengan adanya peningkatan kecepatan layanan dan efisiensi diharapkan akan meningkatkan daya saing lembaga keuangan syariah. Bank Indonesia memprediksi perkembangan fintech syariah sangat potensial apalagi saat ini nasabah perbankan syariah baru mencapai 12 juta nasabah atau hanya $8,8 \%$ dari total nasabah nasional. ${ }^{8}$ Negara seperti Uni Emirat Arab, Canada, Singapura dan Malaysia Fintech Syariah sudah berkembang dan sebagian besar aplikasinya focus pada layanan pemberian pinjaman. Potensi usaha wisata halal dengan kehadiran fintech juga sangat besar. Sementara bersdasarkan data asosiasi fintech Indonesia di saat ini terdapat 184 perusahaan fintech yang bergerak di empat kategori,

\footnotetext{
Suryanti Hidayati and others, 'Kajian Operasional E-Money’ (Bank Indonesia, 2006), 1-5.

Otoritas Jasa Keuangan, Statistik Perbankan Syariah, 2017, 123.

Otoritas Jasa Keuangan, Statistik Perbankan Syariah, 2015, 112-115.
} 
diantaranya kategori simpanan, pembiayaan, dan pengumpulan modal, kategori investasi dan manajemen resiko serta kategori penyediaan. ${ }^{9}$ Mayoritas pelaku fintech berasal dari ketegori payment yang jumlah pelakunya mencapai $77 \%$ penyelenggara fintech .

Perkembangan teknologi dan kecepatan informasi tersebar lebih cepat dari pada aturan hukum itu sendiri, atau kadang masyarakat terjebak pada label syariah sehingga tanpa analisa yang mendalam mereka mengikuti begitu saja, dan celakanya kadang kata syariah hanya dijadikan program marketing semata oleh segelintir masyarakat, sehingga banyak penipuan akhir-akhir ini dengan kata Syariah. Agar masyarakat tidak terjebak dengan label syariah yang digaungkan, harus lebih di tekankan kepada masyarakat adalah pemahaman bahwa nilai Syariah itu memiliki kadar, seberapa syariahkah sebuah produk keuangan, sehingga implikasinya masyarakat akan sangat berhati hati, dan tidak terlalu cepat percaya sebelum menganalisis secara mendalam sebuah produk keuangan itu syariah atau hanya lebel semata.

Berdasarkan masalah yang ada, penulis melihat bahwa fenomena tersebut merupakan masalah yang sangat serius sedang dihadapi oleh masyarakat dan pihak lembaga keuangan syariah sendiri. Permasalahan tersebut membutuhkan suatu jawaban yang cepat dan tepat, karena apabila tidak ditanggapi dengan cepat, tepat dan serius maka akan menurunkan kepercayaan masyarakat terhadap industri perbankan syariah dan pada akhirnya akan menganggu pertumbuhan dan perkembangannya di masa yang akan datang. Perkembangan teknologi dan kecepatan informasi lebih cepat dari pada aturan hukum itu sendiri. Agar masyarakat tidak terjebak dengan label syariah yang di gaungkan Justru yang harus lebih di tekankan adalah seberapa syariah lembaga keuangan syariah?

\section{Perkembangan Fintech (Financial Technology)}

Fintech adalah inovasi transaksi keuangan berbasis teknologi guna menyederhanakan transaksi keuangan. Perkembangan fintech di Indonesia terutama yang berbasis startup terus meningkat setiap tahunnya membuat para startup berlomba-lomba untuk mengenalkan produk mereka ke masyarakat. Fintech atau sering dikenal dengan financial technologi diawali ketika terjadi krisis ekonomi di Amerika Serikat dan Eropa yang menimbulkan keinginan masyarakat untuk menciptakan sebuah sistem yang lebih efisien dan tidak menunggu proses birokrasi yang panjang dan memakan waktu lama. Dengan fintech masyarakat Indonesia jadi lebih mudah dalam melakukan transaksi keuangan secara online, meningkatkan pemahaman tentang keuangan, merubah gaya hidup serta mewujudkan inklusi keuangan. Industri Financial Technologi (fintech) menjadi sangat popular dalam layanan keuangan di era digital saat ini. Dengan adanya fintech kedepannya pemerintah dan masyarakat dapat meningkatkan jumlah masyarakat yang memiliki akses pada layanan keuangan. ${ }^{10}$

Perusahaan fintech di Indonesia yang sekarang didominasi oleh startup dengan potensi yang besar, sehingga fintech berkembang cepat ke berbagai sektor seperti ke payment gateway, wealth management, crowdfunding, lending dan lainnya. Oleh karena itu, kita perlu mengetahui jenis-jenis fintech agar kita bisa menyesuaikan dengan kebutuhan kita, dan tidak tertipu oleh tawaran-tawaran produk yang merugikan. Beberapa jenis fintech yang ada di Indonesia adalah sebagai berikut:

\footnotetext{
Hidayati et al., "Kajian Operasional E-Money."

10 Budi Wibowo, Analisa Regulasi Fintech dalam Membangun Perekonomian di Indonesia (Jakarta, Indonesia, 2013), 46
} 


\section{Payment Gateway}

Payement gateway merupakan gerbang transaksi yang sediakan oleh sebuaj layanan aplikasi e-commerce yang bisa memberi otorisasi pemrosesan kartu kredit maupun pembayaran langsung bagi kliennya dalam aktifitas bisnis elektronik atau online. Payement gateway mempermudah pembeli dapat bertansaksi langsung, sedangkan bagi penjual minimasi sumber daya, mudah memeriksa transaksi, reliabilitas tinggi, cepat, data terlindungi, dan aman.

2. Dompet Digital (Digital Wallet)

Selain payment gateway layanan fintech yang juga diminati banyak orang adalah dompet digital (e-wallet). Dengan adanya layanan tersebut akan mempermudah pengguna untuk menyimpan uang dalam bentuk uang virtual dan dapat digunakan untuk bertransaksi di merchant offline maupun online yang tersedia. ${ }^{11}$ Kelebihan dari $e$-wallet yaitu memberikan kemudahan pengguna sehingga tidak perlu membawa uang tunai apalagi membawa uang hasil kembalian. selain itu, dalam metode pembayaran jauh lebih praktis menggunakan $Q R$ code.

3. Manajemen Kekayaan (Wealth Management)

Manajemen kekayaan (Wealth Management) adalah suatu layanan pengelolaan keuangan dan keayaan. Wealth Management berfungsi sebagai manajer keuangan pribadi. Dengan adanya Wealth Management kita dapat mengetahui beberapa indikator keuangan seperti harta yang dimiliki, penghasilan, pengeluaran, jumlah hutang, asuransi dan lain sebagainya. ${ }^{12}$

4. Pembiayaan Sosial (Social Crowdfunding)

Social Crowdfunding merupakan salah satu penghimpunan dana sosial yang sedang populer. Metode yang memungkinkan orang-orang dapat 'patungan' untuk mewujudkan kepentingan sosial. Pada dasarnya Crowdfunding itu melibatkan beberapa pihak dalam melakukan pembiayaannya, seperti orang yang membutuhkan dana, supporter (publik yang memberikan dana) dan penyedia platform Crowdfunding. Ketiga belah pihak saling terhubung satu sama lain untuk dapat menunjang kebutahan pihak lainnya. Adanya platform crowdfunding akan meningkatkan fintech di Indonesia.

5. Peminjaman (Lending)

Dalam membangun sebuah usaha pasti memerlukan modal sehingga rencana yang sudah disusun dapat berjalan dengan baik. Dalam Peminjaman atau Lending ada beberapa segmentasi dari segi tujuan mengajukan pinjaman yaitu pinjaman konsumtif dan pinjaman produktif. Nominal pinjaman untuk pinjaman konsumtif biasanya berkisar di angka Rp 1-3 juta dengan tenor minimum kurang dari 1 minggu dan pinjaman modal UMKM yang nominalnya dapat mencapai Rp 2 miliar dengan tenor 1-24 bulan. ${ }^{13}$

Di Indonesia yang semakin marak ialah situs-situs yang menyediakan fasilitas peminjaman. Terdapat berbagai situs yang memberikan jasa peminjaman keungan yang sistemnya lebih efisien jika dibandingkan dengan sistem yang diterapkan oleh jasa perbankan, tentunya dengan ketentuan yang ditetapkan oleh masing-masing situs tersebut. ${ }^{14}$ Sebagai contoh situs yang menyediakan pinjaman di

11 Nindyo Pramono, 'Revolusi Dunia Bisnis Indonesia Melalui E-Commerce dan E-Business: Bagaimana Solusi Hukumnya', Hukum, Volume 8 (2001), 16-28.

12 M.M Ompian, Behavioral Finance and Wealth Management (Hoboken, New Jersey: John Wiley \& Sons Inc, 2006), 167

13 Hidayati et al., "Kajian Operasional E-Money."

14 Otoritas Jasa Keuangan, Statistik Perbankan Syariah, 2015, 33. 
bawah 300 juta rupiah, 1,5 sampai 2 juta, 2 juta sampai 10 juta rupiah. Artinya layanan ini ditujukan untuk masyarakat menengah ke bawah. Praktek transaksi perbankan mereka masih sangat minim. Hal ini terlihat dari cara transaksi mereka yang tidak sering menggunakan bank dalam aktivitas keuangannya, sehingga sekmen menengah ke bawah lah yang disasar oleh para pemain fintech yang memberikan jasa peminjaman, atau paling tidak adalah segmen menengah karena demografi Indonesia lebih dari 50\% adalah segmen menengah.

\section{Regulasi Fintech di Indonesia}

Fintech dalam bahasa Indonesia disebut teknologi keuangan adalah sistem keuangan yang menggunakan teknologi sehingga menghasilkan produk, layanan, teknologi, dan/atau model bisnis baru yang memberikan dampak pada stabilitas sistem keuangan, serta efisiensi, kamanan, dan kelancaran sistem pembayaran. Berdasarkan pasal 3 Peraturan Bank Indonesia Nomor 19/12/ PBI 2017 tentang teknologi finansial bahwa teknologi finansial ini harus memenuhi kriteria yaitu:

1. Bersifat inovatif

2. Dapat berdampak pada produk, layanan, teknologi dan/atau model bisnis finansial yang telah eksis

3. Dapat memberikan manfaat bagi masyarakat

4. Dapat dipergunakan secara luas

5. Kriteria lainnya yang ditetapkan oleh Bank Indonesia

Bank Indonesia selanjutnya membagi penyelenggaraan fintech ke dalam lima macam kategori berdasarkan jenis inovasi yaitu :

Pertama, sistem pembayaran. Sistem pembayaran yaitu mencakup otoritas, kliring, penyelesaian akhir dan pelaksanaan pembayaran. Contoh, penggunaan teknologi blockchain atau distributed ledger dalam pelaksanaan tranfer dana, e-money, e-wallet dan mobile payments. Kedua pendukung pasar. Pendukung pasar adalah penggunaan teknologi informasi dan/atau teknologi elektronik pada fintech tersebut, sehingga dapat memberikan informasi yang cepat dan produk atau layanan yang murah. Contoh, penyediaan data perbandingan informasi produk atau layanan jasa keuangan. Ketiga, Manajemen Investasi dan Manajemen Resiko. Implementasi dari manajemen investasi dan manajemen resiko yaitu adanya layanan investasi online dan asuransi online. Keempat, pinjaman, pembiayaan, dan penyediaan modal. Penyelenggaraan fintech pada kategori pinjaman (lending), pembiayaan (financing atau funding), dan penyediaan modal (capital rising) antara lain layanan pinjam meminjam uang berbasis teknologi informasi (peer-to-peer lending) serta pembiayaan atau penggalangan dana berbasis teknologi informasi (crowd-funding). Kelima, jasa finansial lainnya. Dalam perkembangan fintech sampai saat ini masih sedikit regulasi yang mengatur hal tersebut. Belum ada peraturan perundang-undangan yang mengatur secara khusus tentang fintech. Akan tetapi, Otoritas Jasa Keuangan (OJK) dan Bank Indonesia (BI) sesuai dengan kewenangannya yang mengatur dan mengawasi industri jasa keuangan telah mengeluarkan beberapa regulasi untuk mengatur fintech yang sedang berkembang pesat ini. Berikut adalah beberapa regulasi tersebut :

1. Peraturan Otoritas Jasa Keuangan (POJK) Nomor 77/POJK.01/2016 tentang Layanan Pinjam Meminjam Uang Berbasis Teknologi Informasi (LPMUBTI). 
2. Peraturan Bank Indonesia (PBI) Nomor 18/40/PBI/2016 tentang Penyelenggaraan Pemrosesan Transaksi Pembayaran (PTP), Sebagaimana dilansir dari laman resminya, terbitnya PBI Nomor 18/40/PBI/2016 ini bertujuan untuk memenuhi kebutuhan masyarakat, termasuk di bidang jasa sistem pembayaran, baik dari sisi instrumen, penyelenggara, mekanisme maupun infrastruktur penyelenggaraan pemrosesan transaksi pembayaran.

3. Peraturan Bank Indonesia (PBI) Nomor 19/12/PBI/2017 tentang Penyelenggaraan Teknologi Finansial.

\section{Fintech Syariah di Indonesia}

Layanan industri jasa keuangan digital atau financial technology (fintech ) semakin beragam jenisnya di masyarakat. Setelah ada uang elektronik (e-payment), asuransi teknologi (insuretech), pinjaman online atau fintech peer to peer (P2P) konvensional, kini mulai berkembang di masyarakat fintech syariah. Sebenarnya, jenis ini termasuk kategori fintech P2P karena inti bisnisnya memberi pendanaan kepada peminjam. Namun, sesuai namanya, fintech syariah menerapkan prinsip-prinsip Islam dalam transaksinya. Sehingga, terdapat perbedaan dalam bunga atau riba, akad, mekanisme penagihan hingga penyelesaian sengketa.

Payung hukum fintech syariah juga berlandaskan Peraturan Otoritas Jasa Keuangan (POJK) 77 Tahun 2016 tentang Layanan Pinjam Meminjam Uang Berbasis Teknologi Informasi. Aturan ini memang mengatur secara umum setiap jenis fintech P2P seperti fintech syariah dan konvensional. Namun, fintech syariah juga mengacu Fatwa Dewan Syariah Nasional Majelis Ulama Indonesia (DSN MUI) Nomor 117/2018 tentang Layanan Pembiayaan Berbasis Teknologi Informasi Berdasarkan Prinsip Syariah. DSN MUI tersebut menjelaskan fintech syariah merupakan layanan jasa keuangan yang menggunakan prinsip syariah Islam yang dimana mempertemukan atau menghubungkan antara investor dan peminjam untuk melakukan suatu akad pembiayaan melalui sistem elektronik menggunakan jaringan internet.

Financial Technology dengan sistem syariah pertama kali muncul di Dubai, Uni Emirat Arab. Pada tahun 2014 silam, Beehive berhak mendapatkan sertifikat yang pertama dengan menggunakan pendekatan peer to peer lending marketplace..$^{15}$ Berawal dari Beehive, fintech syariah mulai dipraktekkan di berbagai negara di Asia, seperti Singapura dan Malaysia. Menurut OJK (2018) sekitar 40\% penduduk Indonesia masih belum melakukan pembukaan akun dengan bank apapun. Akan tetapi, hampir semua penduduk Indonesia memiliki smartphone. Jadi, adanya fintech akan mempengaruhi perkembangan bank konvensional di era digital yakni menggunakan teknologi kedalam sistem keuangannya.

Pengembangan bisnis melalui finansial teknologi syariah sudah dilakukan sejak berdirinya asosiasi fintech Indonesia pada tahun 2016, bahkan hingga 2019 sudah ada lebih dari 6 Fintech Syariah yang terdaftar di Otoritas Jasa Keuangan. ${ }^{16}$ Perbedaan fintech konvensional dengan syariah terletak pada proses akad yang lakukan pemilik usaha dan inventor. Akad Mudarabah adalah kerjasama antara pemilik usaha dan pemilik modal (investor) dimana keuntungan dibagi secara adil, namun apabila ada kerugian hanya pemilik modal yang bertanggung jawab. Sedangkan, Akad Musyārakah adalah kerjasama yang dilakukan antara kedua belah pihak dengan sistem bagi rata baik itu keuntungan dan kerugian. Salah satunya adalah sama dengan yang ada di perbankan, asuransi atau pembiayaan

15 Keuangan, Statistik Perbankan Syariah, 2017.

16 Otoritas Jasa Keuangan, Statistik Perbankan Syariah, 2017. 
syariah pasti ada syariah complaint. Artinya kegiatan ini dilakukan dengan prinsip syariah, jadi ketika dalam melakukan pembiayaan kepada peminjam harus digunakan untuk kegiatan yang tidak bertentangan dengan syariah. Kemudian dari sisi akad, itu bisa menggunakan mudharabah atau musyarakah. Kemudian yang menjamin fintech syariah itu syariah atau tidak diawasi oleh Dewan Pengawas Syariah itu juga berlaku untuk perbankan, asuransi dan pembiayaan syariah.

Minimal ada 4 tahapan agar perusahan fintech menjadi fintech Syariah menurut Majelis Ulama Indonesia (MUI):

1. Perusahan terdaftar di OJK (Otoritas Jasa Keuangan) / Bank Indonesia.

2. Melengkapi Desk Review di DSN MUI.

3. Perusahaan melakukan presentasi dihadapan tim Visitasi dari DSN MUI.

4. Mendapat rekomendasi Dewan Pengawas Syariah (MUI).

Selain akad, pengawasan terhadap perusahaan fintech itu sangat penting untuk menjaga marwah fintech syariah. Setidaknya ada 4 pengawas yaitu Auditor Internal, Auditor Eksternal, OJK/ BI dan Dewan Pengawas Syariah (MUI). Apabila melakukan transaksi menggunakan smartphone, seperti membeli makanan ataupun memesan ojek, itu berarti Anda merupakan salah satu orang yang menggunakan fintech. Secara umum, Fintech menjadi alternatif lain dalam bidang jasa keuangan yang tadinya menggunakan uang kertas sekarang dapat menggunkan uang virtual (e-money). Dengan kata lain, keberadaan financial technology mengubah mata uang menjadi digital agar lebih efisien.

Di Indonesia sendiri, perkembangan fintech sangat terlihat jelas. Bahkan, dalam 10 tahun terakhir, tercatat ada lebih dari 180 perusahaan yang mendaftarkan diri ke Otoritas Jasa Keuangan. ${ }^{17}$ Walaupun begitu, baru ada sekitar 63 perusahaan saja yang tercatat secara resmi di Indonesia, sedangkan sisanya tengah mengajukan surat konfirmasi tersebut kepada OJK. Kedepannya, bukan tidak mungkin, keberadaan fintech bisa menjadikan bank konvensional tergusur.

Pada awalnya fintech di Indonesia menggunakan konsep konvensional. Akan tetapi pada tahun 2018, beberapa fintech mulai mengadopsi konsep syariah yang menggunakan dasar-dasar dari aturan agama Islam. Pada dasarnya tidak ada perbedaan dalam fungsi fintech konvensional dengan syariah, keduanya sama-sama bertujuan untuk memberikan layanan keuangan. Adapun yang membedakan antara keduanya hanyalah akad pembiayaan saja yang mana mengikuti prinsip-prinsip syariah Islam yaitu tidak boleh maisir (bertaruh), gharar (ketidakpastian) dan riba (jumlah bunga melewati ketetapan).

Walaupun menggunakan prinsip-prinsip syariah, dasar rujukan telah dibuat oleh Dewan Syariah Nasional terkait dengan keberadaan financial technology syariah. Dasarnya adalah MUI No.67/ DSN-MUI/III/2008 yang mengatur tentang ketetapan apa saja yang harus diikuti lembaga teknologi keuangan terbaru di Indonesia tersebut. Terhitung hingga September 2018, baru ada 4 perusahaan teknologi keuangan syariah yang diresmikan oleh OJK. Sisanya, 90\% perusahaan fintech di Indonesia masih menggunakan konsep konvensional. Sedangkan peraturan berkaitan dengan orang telat membayar peminjaman diatur oleh peraturan No.17/DSN-MUI/IX/2000, jika sanksi akan diberikan kepada nasabah yang tidak melunasi hutangnya pada tenggat waktu tertentu.

Sebagai lembaga pengawas, OJK belum membuat regulasi pasti berkaitan dengan keberadaan perusahaan fintech syariah. Namun, Dewan Syariah Nasional MUI (2000) telah mengeluarkan fatwa

17 Otoritas Jasa Keuangan, Statistik Perbankan Syariah, 2019, 23 
bahwa perusahaan fintech syariah harus mengikuti aturan syariah Islam yakni terbebas dari unsur riba dan sesuai dengan akad mud̄ārabah dan musyārakah.

Akad mudārabah merupakan akad kerjasama antara dua belah pihak yakni pemilik modal dan pengelola dana. Keduanya saling bertemu untuk besar keuntungan yang akan dibagi secara adil. Akan tetapi, kerugian itu ditanggung oleh pemilik modal kecuali jika kesalahan dilakukan oleh pengelola dana. Sebenarnya akad musyārakah sama dengan akad mudāarabah, perbedaannya terletak pada penanggung jawab ditanggung oleh kedua belah pihak.

Perkembangan fintech syariah dengan kerangka Interpretive Struktural Model (ISM) terdiri dari empat kriteria diantaranya: (1) perspektif fungsi fintech, (2) masalah yang dihadapi dalam mengembangkan fintech syariah, (3) strategi atau dasar pijakan yang diperlukan dalam kerangka pengembangan fintech syariah, dan (4) ekosistem atau aktor yang terlibat dalam pengembangan fintech syariah di Indonesia. ${ }^{18}$

\section{Menakar Hukum Fintech Syariah}

Landasan utama dalam mengukur seberapa syariahkan fintech syri'ah adalah dengan menggunakan landasan Al-Quran, hadits dan ijtihad. Dikarenakan fintech merupakan produk baru masyarakat, maka peran ijtihad lebih dominan, tanpa meninggalkan norma muamalah yang sudah ditetapkan oleh ulama salaf.

Islam memiliki beberapa dasar hukum yang berfungsi mengatur setiap tatanan manusia dalam melakukan aktivitasnya. Beberapa dasar hukum Islam yang memberikan argumen terkait permasalahan diatas adalah salah satunya tentang pemaparan Allah ketika mengharamkan riba dan menghalalkan jual beli:

1. Al-Quran

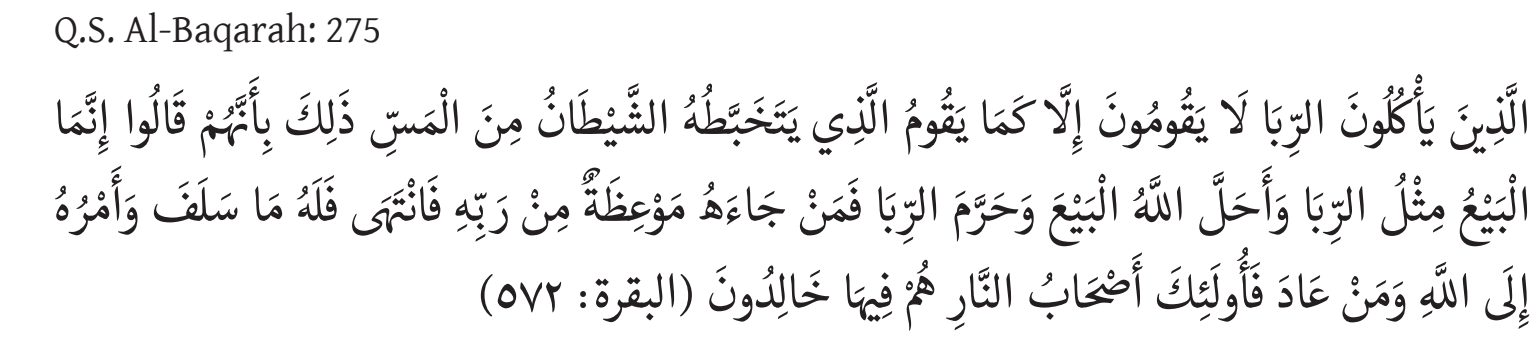

Orang-orang yang makan (mengambil) riba tidak dapat berdiri melainkan seperti berdirinya orang yang kemasukan syaitan lantaran (tekanan) penyakit gila. Keadaan mereka yang demikian itu, adalah disebabkan mereka berkata (berpendapat), sesungguhnya jual beli itu sama dengan riba, padahal Allah telah menghalalkan jual beli dan mengharamkan riba. Orang-orang yang telah sampai kepadanya larangan dari Tuhannya, lalu terus berhenti (dari mengambil riba), maka baginya apa yang telah diambilnya dahulu (sebelum datang larangan); dan urusannya (terserah) kepada Allah. Orang yang kembali (mengambil riba), maka orang itu adalah penghuni-penghuni neraka; mereka kekal di dalamnya.

Pilihan diksi dari ayat diatas adalah al-bay' dan al-ribā yang memiliki maksud dan tujuan bahwa hukum yang betul-betul diperbolehkan oleh Allah adalah jual beli dan Allah juga

18 Aam Slamet Rusdyana, "Bagaimana Pengembangan Industri Fintech Syariah di Indonesia? Pendekatan Interpretive Structural Model," al-Muzara'ah Volume 62 (2018), 117-128. 
sekaligus menegaskan tentang keharaman riba. Menurut Liaquat: in this verse "the money-lender" is likened to a madman. Just as a madman loses his sense on account of his disordered intellect, in the same way the money-lender us so concerned with money-making that he divorces himself from common sense. ${ }^{19}$

Dalam tafsir al-Qusyairi dimaknai sebagai berikut:

$$
\begin{aligned}
& \text { من أعرض عن الأمر، ورخِّص لنفسه بما يسوِّله له خاطره من التأويل فلا استقلال لهم فن الحال ولا } \\
& \text { انتعاس فى المآل خسروا فى عاجلهم ولم يربكوا فى آجلهم } 20
\end{aligned}
$$

Al Quran di samping menjelaskan tentang jual beli dan riba juga menjelaskan tentang perbuatan yang bātil (salah/tidak tepat), sebagaimana pesan al-Nisā: 29:

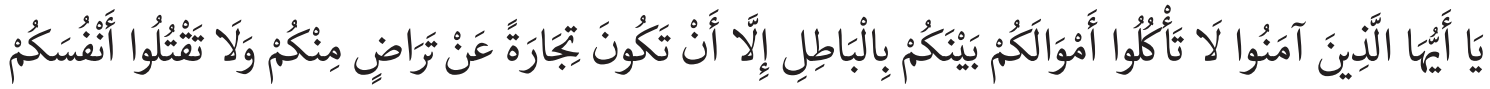

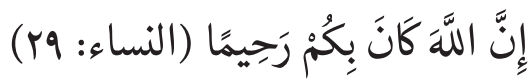

"Hai orang-orang yang beriman, janganlah kamu saling memakan harta sesamamu dengan jalan yang batil, kecuali dengan jalan perniagaan yang Berlaku dengan suka sama-suka di antara kamu. dan janganlah kamu membunuh dirimu; Sesungguhnya Allah adalah Maha Penyayang kepadamu".

Diksi dalam ayat tersebut adalah al-bāțil, yakni setiap perbuatan yang akan merugikan diri sendiri maupun orang lain, termasuk di dalamnya transaksi fintech yang dapat merugikan para pihak. Dalam pandangan Quraish shihab makna al-bātili, yakni pelanggaran terhadap ketentuan agama atau persyaratan yang disepakati. Dalam konteks ini, Nabi saw bersabda, "kaum muslimin sesuai dengan (harus menepati) syarat-syarat yang mereka sepakati, selama tidak menghalalkan yang haram atau mengharamkan yang halal. ${ }^{21}$

- Q.S. Al-Baqarah: 282

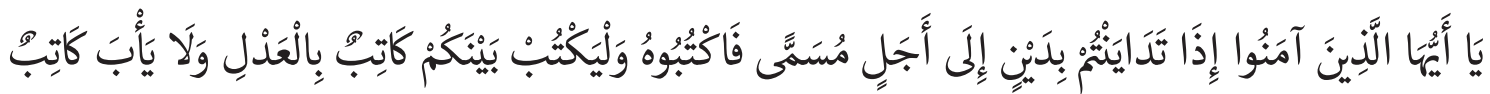

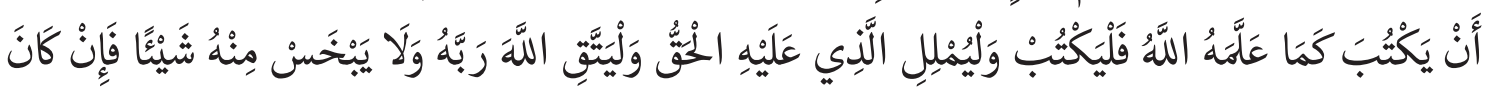

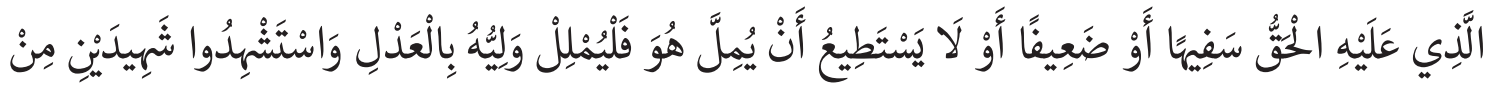

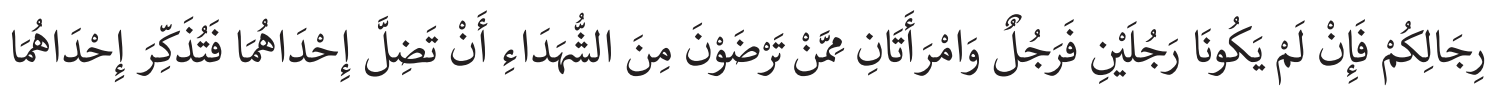

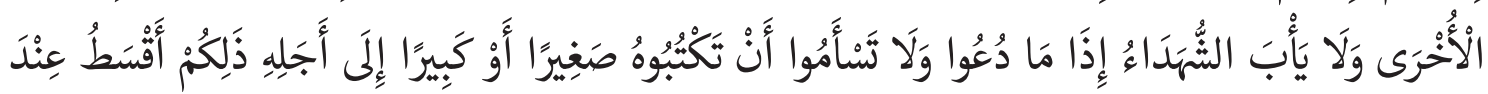

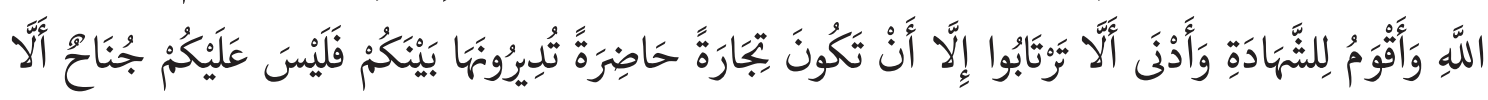

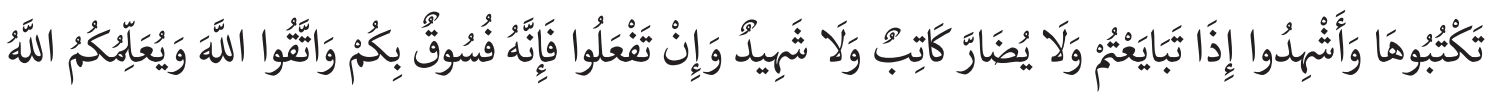

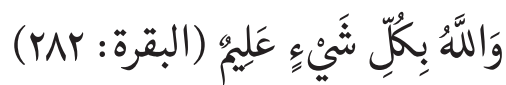

Diksi yang berkenaan dengan muamalah dalam dalil ini adalah dayn (utang) yakni uang yang diakadkan sebagai pinjaman dari pemilik uang ke pengambil manfaat uang harus tercatat baik

19 Liaquat Ali Khan Niazi, Islamic Law Contract (Pakistan, research cell, Dyal sing trust Library Nisbet Road lahore, 1990), $255-256$.

20 Abdul Karīm bin Hawāzin al-Qusyairī, Lațā̉if al-Isyārāt (Beirut: Dār al-Kutub al-Islamiyah, 2017), I: 127.

21 M. Quraish Shihab, Tafsir Al-Misbah: Pesan, Kesan dan Keserasian al-Quran (Jakarta: Lentera Hati, 2002), 413. 
secara manual maupun secara digital. Menurut Imam al-Qurțūbi harus dilakukan pencatatan dalam rangka untuk saling mengingatkan dan menghindari adanya pengingkaran.

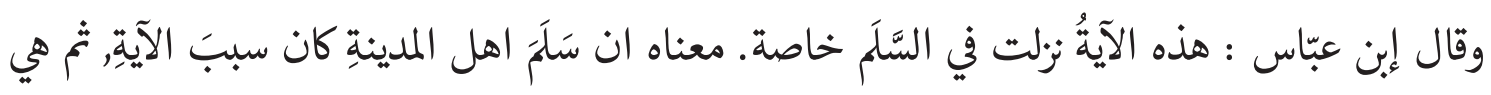

$$
\begin{aligned}
& \text { تثناول جميعَ المداينات إجماعا.22 }
\end{aligned}
$$

Dari apa yang disampaikan Ibn Abbas dapat dipahami bahwa setiap transaksi yang dilakukkan secara tidak langsung dikategorikan sebagai Salam. Maka, transaksi ini mencakup salam ini dapat mencakup online maupun fintech. Dari banyaknya fintech yang berkembang dimasyarakat tentunya menuimbulkan banyak nasabah yang melakukan perbuatan tidak menyenangkan yang dapat merubah hukum dari berpahala menjadi berdosa. Hal ini diatur dalam Q.S. Al-Baqarah: 198.

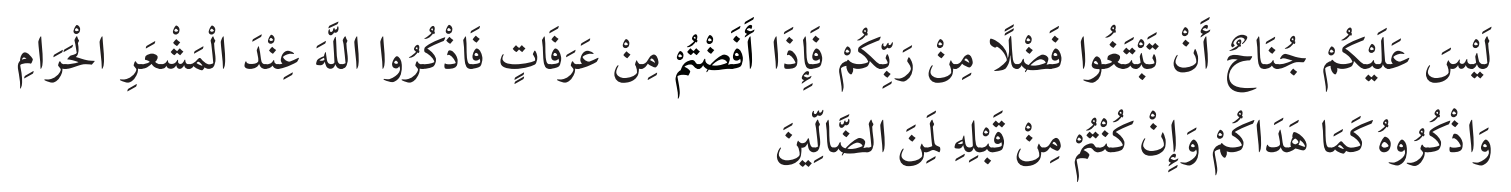

Diksi dari ayat trsebut berkenaan dengan makna fadlan, maknanya manusia dapat mengambil manfaat dari apa yang telah disediakan Allah.

2. Hadis

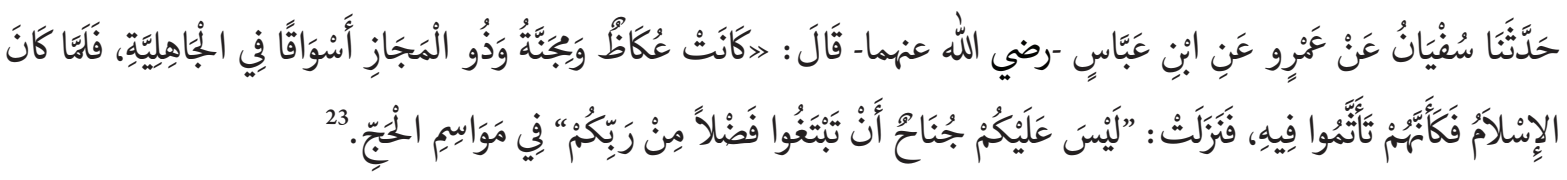

Telah berata kepada kita sufyan dari 'Amr dari ibn Abās "Dahulu pasar 'ukaz, pasar mijannah, dan pasar dzu al-majāz merupakan pasar pada masa jahiliah, ketika pada masa islam orang-orang islam merasa berdosa untuk menghidupkan pasar-pasar tersebut kemudian turun ayat: tidak berdosa bagi kalian untuk mencari karunia dari Tuhan kamian-pada musim haji-. (H.R. Bukhori dari Ibnu Abas)

Pesan yang dikehendaki oleh hadits tersebut di atas adalah, sistem perekonomian dan keuangan sebelum masa Islam terkadang diadopsi oleh sistem perekonomian dan keuangan dalam Islam dengan mengikuti aturan-aturan yang sesuai dengan ketentuan syari'at Islam. Namun, disisi lain diingatkan oleh Rasulullah saw, dalam sebuah hadits yang diriwayatkan oleh Rifā'ah "sesungguhnya para pengusaha dibangkitkan pada hari kiamat kelak sebagai fujjāran (orang orang yang celaka), kecuali mereka yang berbuat benar dan jujur dalam pernaiagaannya. ${ }^{24}$

3. Kaidah Fikih mengenai keabsahan transaksi

$$
\text { يشتترط لصحة التكليف أن يكون المكلِّف عالماً بماكلِفت به }
$$

Syarat sah sebuah transaksi adalah pelaku transaksi mengetahui dan memahami apa yang dilakukan bahkan kemungkinan resiko yang menyertai transaksi yang dilakukannya. ${ }^{25}$

22 Muhammad bin Ahmad bin Abi Bakr al-Qurțūbī, Jāmi 'Ahkāmi al-Qurān (Beirut: Muasasah al-Risālah, 2006), IV: 423.

23 Muhammad ibn Imsā’il al-Bukharī, Al-jāmi' al-Musnad al-Ṣaḥiḥ al-Mukhtașar min Umūr Rasulullah Șallallah 'alaihi Wasallam wa Sunnanih wa Ayyamih, ed. by Muhammad Z̄āhir bin Nāșir (Bairūt: Dār al-Ṭūq al-Najāh, 1422), III/53.

24 Ali Ahmad al-Salusī, Mawsū'ah al-Qadāyāa al-Fiqhiyah al-Mu'āșirah wa al-Iqtiṣād al-Istāmī (Mesir: Maktabah Dār al-Quran, 2004), 233.

25 Abi Hasan 'Alaudin bin Muhammad 'Abas, al-Qawā'id wal Fawaid al-Ușūliyah (Beirūt: Maktabah al-'Așriyah, 2002$), 66$. 
Disebutkan dalam al-Qur’an bahwa salah satu dasar utama diutusnya Nabi Muhamamd saw adalah agar membebaskan manusia dari segala bentuk kebodohan dan ikatan yang membelenggunya. Kesejahteraan ummat nabi dalam Islam menempati urutan penting baik manusia sebagai individu maupun sosial bahkan islam memiliki komitmen terhadap kebebasan manusia sebagai individu lebih mendalam dibanding sistem agama yang lain terutama terhadap kegiatan perekonomian dan keuangan.

Pembelian dan penjualan secara online diperbolehkan dalam syariah, para pelaku bisnis online dapat memperoleh laba dengan baik. Namun, hal ini menjadi salah satu akar timbulnya ketidakadilan karena kedua belah pihak memiliki target keunntungan yang lebih. Sementara, hukum syariah memberikan warning agar tidak mengambil keuntungan secara berlebihan. ${ }^{26}$

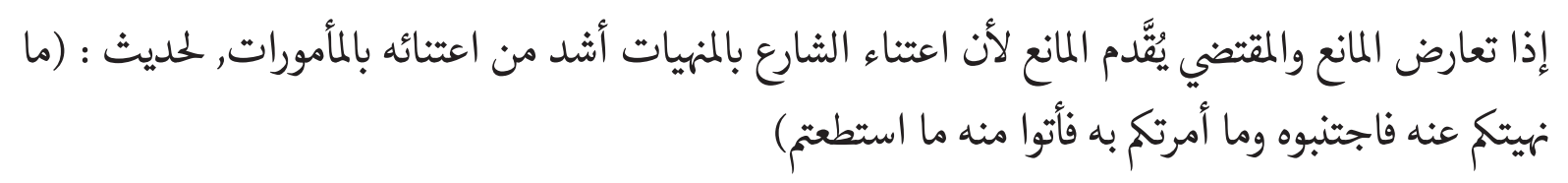

Jika ada dua hal yang saling bertentangan, hasrat untuk memperoleh keuntungan sebanyakbanyaknya dan potensi perolehan keuntungan yang telah mencukupi biaya produksi dan distribusi (operasional) maka dahulukan pencegahan dibanding memenuhi perolehan hasrat tersebut hal ini adalah pengejawentahan dari salah satu kaidah fikih di atas. ${ }^{27}$

Berdasarkan beberapa dalil diatas dapat diambil kesimpulan bahwa hukum merupakan suatu dasar yang dijadikan acuan antara boleh dan tidaknya seseorang melakukan sesuatu baik dalam ibadah maupun aktivitas lainnya. Dimana tujuan hukum itu sendiri mempunyai sifat universal seperti ketertiban, ketenteraman, kedamaian, kesejahteraan dan kebahagiaan dalam tata kehidupan bermasyarakat. Dengan adanya hukum maka tiap perkara dapat di selesaikan melaui proses pengadilan dengan prantara hakim berdasarkan ketentuan hukum yang berlaku,selain itu hukum juga bertujuan untuk menjaga dan mencegah agar setiap orang tidak dapat menjadi hakim atas dirinya sendiri. ${ }^{28}$

Setelah mengambil dari beberapa dalil, refrensi, data-data dan kasus yang terjadi terkait fintech, maka dibutuhkan pemahaman mendalam tentang menetukan seberapa syariahkah fintech di Lembaga Syariah dari aspek utama yang telah diijtihadkan oleh para ulama salaf yakni terhindar dari ribawi, maysir, gharar, risywah, tadlis, israf, dan kehalalan. Namun, untuk transaksi Fintech perlu ditingkatkan lagi literasi tentang kesyariahan agar nilainya meningkat, sebagaimana dalil dan hasil ijtihad diatas juga perlu diksi baru seperti:

1. Akuntabilitas

Pilihan diksi dari surat al-Nisa: 59 adalah ketaatan kepada pemerintah dalam hal ini ketaatan kepada regulasi yang telah ditetapkan oleh pemerintah. Allah berpesan:

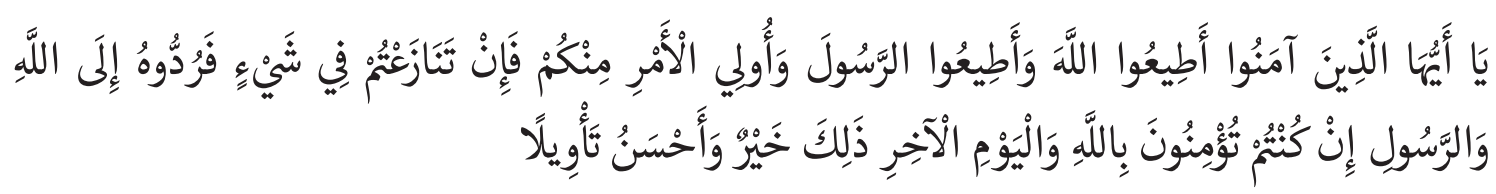

\footnotetext{
${ }^{6}$ Abi Hasan 'Alaudin bin Muhammad 'Abas, al-Qawā'id wal Fawaid al-Ușūliyah (Beirūt: Maktabah al-'Așriyah, 2002$), 67$.

7 Ahmad bin Muhammad al-Zarqā, Syarah Qawā'id al-Fiqhiyah (Damaskus: Dār al-Qalam, 2001), 243.

${ }_{28}$ al-Salusi, Mawsü'ah al-Qadāya al-Fiqhiyah al-Mu'āṣirah wa al-Iqtișād al-Islāmī.
} 
Banyaknya fintech bermasalah dan merugikan masyarakat adalah ketidak taatanya kepada aspek peraturan-perundang undangan yang berlaku. Ketaatan dan kepatuhan terhadap pemangku kepentingan dan ulil amri dalam hal ini mematuhi peraturan BI dan OJK. Nilai kadar kehalalan akan bertambah apabila semua aspek yang diatur oleh BI dan OJK dipenuhi oleh para pelaku transaksi Fintech.

2. Adil dalam bertransaksi

Dalam Q.S. al-Baqarah: 279 Allah berfirman :

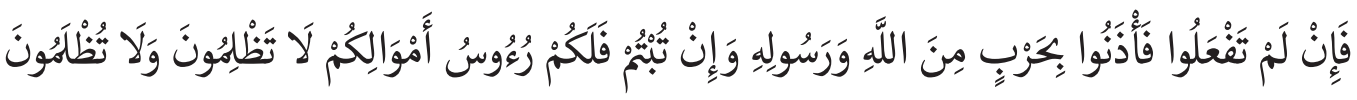

Memiliki hak yang sama yang telah disepakati dan difahami terutama yang berkenaan dengan kesahihan transaksi. Jika pengguna modal membayar angsurannya sesuai kesepakatan didalam bertransaksi tidak terdapat reward, akan tetapi apabila dalam membayar tagihan mengalami keterlambatan maka di kenakan punishmen, dan punishment kadang nilanya sangat tinggi serta memberatkan pengguna modal. Jadi, agar memiliki nilai kehalalan yang lebih tinggi antara reward dan punishment seimbang.

3. Tranparansi Informasi

Dalam Surah al-Nahl: 116 dijelaskan :

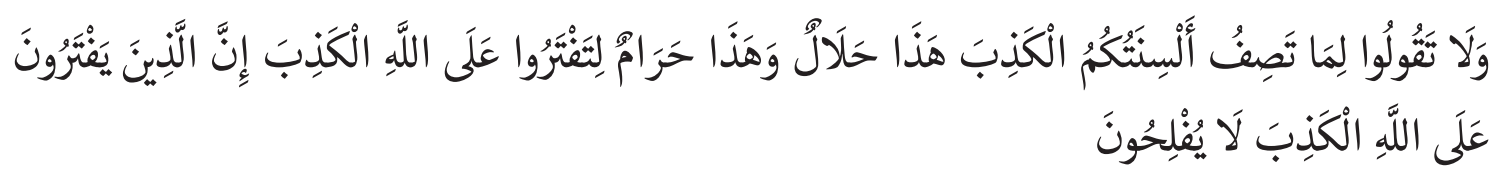

Informaasi yang disajikan tidak mengandung unsur kebohongan. Informasi sebagai media marketing di narasikan harus sesuai dengan keadaan dan tidak melebih-lebihkan, sehingga yang ada dalam fikiran pengguna dana hanya terbesit keuntungan tanpa memikirkan resiko. Sehingga yang terjadi adalah berfikir sesaat akibat dari tidak adanya transparansi informasi.

Meminta informasi secara berlebihan yang mennjadi privasi individu tidak seharusnya diminta oleh para pemilik modal (Investor) karena dapat disalahgunakan oleh orang-orang yan tidak bertanggung jawab.

Pencantuman tokoh atau public figure dalam promosi fintech kadang dijadikan sebagai penguat nilai-nilai kesyariahan, yang sesungguhnya tidak ada relevansinya dengan nilainilai kesyariahan. Begitu juga banyaknya nama perusahaan yang disamarkan terkait identitas perusahaan mengakibatkan banyaknya penipuan sehingga akan kesulitan untuk dilacak. Maka seorang pencari dana harus betul-betul memperhatikan syarat-syarat fintech legal sesuai dengan peraturan yang berlaku yang berkenaan dengan transparansi informasi.

4. Kewajaran

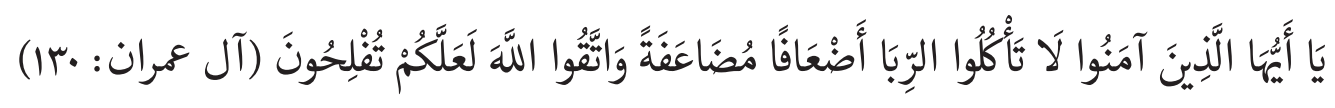

Keuntungan yang didapat tidak melanggar syariat, artinya bagi hasilnya tidak terlalu tinggi dan tidak terlalu rendah yang mengakibatkan kedzoliman. Jika bagi hasilnya terlalu tinggi seringkali mengandung unsur penipuan. Karena bagi hasil yang terlalu tinggi kepada salah satu pihak bisa mengakibatkan ketidakmampuan pengguna dana untuk melunasi. 
Disisi lain keuntungan yang terlalu besar sering dijadikan dalih oleh orang-orang yang tidak bertanggung jawab untuk mengambil keuntungan dengan pola penipuan.

Kewajaran dibutuhkan karena nilai yang berlebihan yang diinformasikan dalam bisnis Fintech dapat menghipnotis pengguna dana sehingga tidak berfikir panjang dan tidak berfungsinya akal sehat, hal ini dapat berimplikasi merugikan diri sendiri dimasa yang akan datang bagi pengguna dana. Menurut Liaquat Ali Khan Niazi commandment forbids muslims to take compound interest (usury) if they want real and lasting happiness, peace of mind and success in life. ${ }^{29}$

5. Kesetaraan

Dalam Surat Al-Mujadalah: 11, Allah Berfirman :

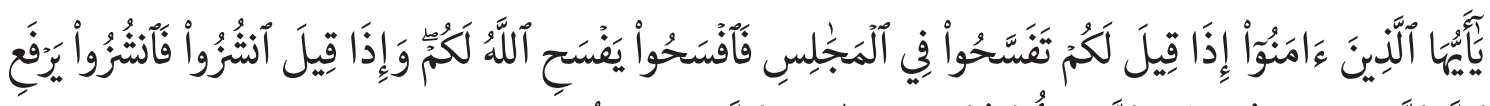

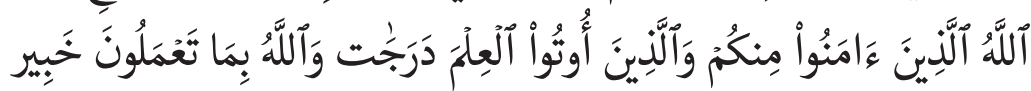

Dari dalil tersebut ketika ada perbedaan pendapat antar pemilik modal dengan pengguna modal diberikan ruang argumentasi atau diskusi dalam menyelesaikan masalah. Banyak aspek yang harus diperhatikan oleh para pemilik modal salah satunya adalah seberapa ungent argumentasi pengguna modal ketika terjadi one prestasi, dan banyak aspek lain yang harus diperhatikan berkenaan dengan kesetaraan, agar para pihak merasa win win solution/ "legowo" ketika menyelesaikan permasalahan.

6. Kesalehan sosial

Allah berpesan dalam surat al-Taubah: 71

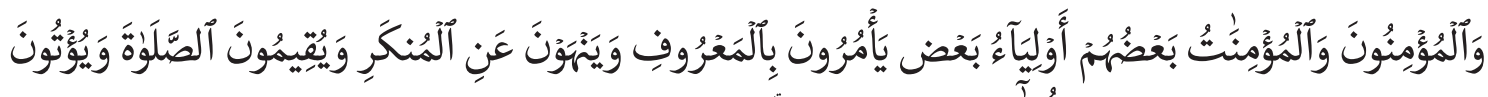

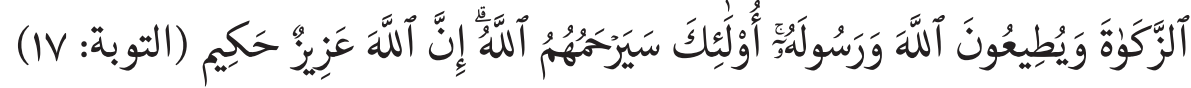

Zakat adalah ukuran berertika dan tidaknya seseorang pengusaha. Siapa saja yang menghitung dan menyalurkan zakatnya sesuai syariat maka merekalah yang di katakan sebagai pengusaha fintech dan berbasis Syariah.

7. Kerahasiaan

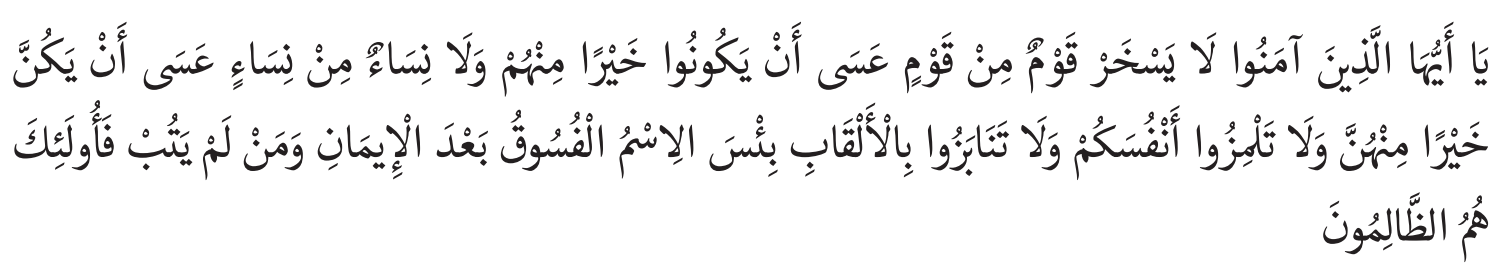

Dalil tersebut menunjukan bahwa merahasiakan kelemahan orang itu berpahala, hal yang harus dihindari adalah menjauhi untuk mencari-cari keburukan/kesalahan orang, dan menggunjingkan satu sama lain, dalama kondisi apapun termasuk ketika bermuamalah.

Penyebaran informasi pengguna dana dalam penagihan bisnis fintech, yang dilakukan oleh pemilik dana/kreditor dengan pola penagihan intimidatif dengan menyebar informasi yang negatif akan berdampak pada tekanan psikologis dan itu berdosa. Dalam Tafsir al-Ṭabarai dikatakan:

\footnotetext{
29 Liaquat Ali Khan Niazi, Islamic Law Contract (Pakistan, research cell, Dyal sing trust Library Nisbet Road lahore, 1990$), 255$.
} 


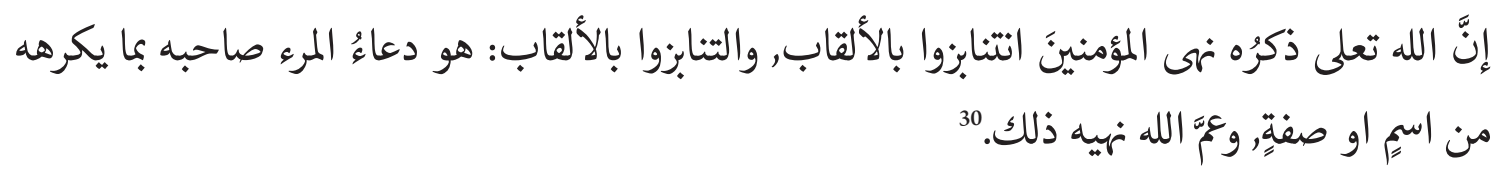

Berdasarkan dalil-dalil diatas masyarakat dapat lebih selektif dalam bermuamalah dan tidak terjebak dama syariah label, akan tetapi bermuamalah dengan muamalah "label" dan "hakikat" syariah. Begitu juga ketika memilih fintech itu syariah dalam label atau syariah dalam hakikat, menyadari bahwa kehalalan fintech bisa memiliki kadar, tergantung seberapa besar aspek-aspek kesyariahan terpenuhi dalam bermuamalah.

\section{Model Pengukuran Kehalalan Produk Fintech Syariah}

Berdasarkan dalil-dalil diatas maka sesungguhnya mengukur kehalalan fintech syariah tidak bisa sebatas dalam teoritik belaka, akan tetapi wajib mengetahui praktik yang sebenarnya terjadi sebelum menyatakan sebuah produk itu halal atau haram baik berupa Payment Gateway, Dompet Digital (Digital Wallet), Manajemen Kekayaan (Wealth Management), Pembiayaan Sosial (Social Crowdfunding), Peminjaman (Lending) dan lainnya.

Salah satu contohnya adalah seperti dalam table di bawah ini.

Tabel 1

Contoh Mengukur Tingkat Kehalalan Produk

\begin{tabular}{|c|c|c|c|}
\hline \multirow[b]{2}{*}{ Nama Product } & \multirow[b]{2}{*}{ Aspek kehalalan } & \multicolumn{2}{|c|}{ Kehalalan } \\
\hline & & Terpenuhi & $\begin{array}{c}\text { Tidak } \\
\text { Terpenuhi }\end{array}$ \\
\hline \multirow{12}{*}{$\begin{array}{l}\text { Payment } \\
\text { Gateway } \\
\text { (PT Sejahtera) }\end{array}$} & Akuntabilitas & $\sqrt{ }$ & \\
\hline & Adil dalam Bertransaksi & $\checkmark$ & \\
\hline & Transparansi Informasi & & $\sqrt{ }$ \\
\hline & Kewajaran & $\sqrt{ }$ & \\
\hline & Kesetaraan & $\sqrt{ }$ & \\
\hline & Kesalehan Sosial & $\sqrt{ }$ & \\
\hline & Kerahasiaan & & $\sqrt{ }$ \\
\hline & Terhindar dari Riba & $\sqrt{ }$ & \\
\hline & Terhindar dari israf & $\sqrt{ }$ & \\
\hline & Terhindar dari gharar & & $\sqrt{ }$ \\
\hline & Terhindar dari risywah & $\sqrt{ }$ & \\
\hline & Terhindar dari tadlis & $\sqrt{ }$ & \\
\hline \multicolumn{2}{|l|}{ Jumlah } & 9 & 3 \\
\hline \multicolumn{2}{|c|}{ Prosentase Kehalalan } & $75 \%$ & $25 \%$ \\
\hline
\end{tabular}

30 Isham Faris Al-Hurasan, Kitab ‘Tafsir Thabari;Jaami Al-Bayan an Ta’wil Aayil Qur'an' (Bairut: Muasasah Al-Risalah, 1994),Pages 83 
Tabel 2

Contoh Mengukur Tingkat Kehalalan Produk

\begin{tabular}{|c|c|c|c|}
\hline \multirow[b]{2}{*}{ Nama Product } & \multirow[b]{2}{*}{ Aspek kehalalan } & \multicolumn{2}{|c|}{ Kehalalan } \\
\hline & & Terpenuhi & $\begin{array}{c}\text { Tidak } \\
\text { Terpenuhi }\end{array}$ \\
\hline \multirow{12}{*}{$\begin{array}{l}\text { Peminjaman } \\
\text { (Lending) (PT } \\
\text { Mundur Maju) }\end{array}$} & Akuntabilitas & & $\sqrt{ }$ \\
\hline & Adil dalam Bertransaksi & & $\sqrt{ }$ \\
\hline & Transparansi Informasi & & $\sqrt{ }$ \\
\hline & Kewajaran & & $\sqrt{ }$ \\
\hline & Kesetaraan & $\sqrt{ }$ & \\
\hline & Kesalehan Sosial & & $\sqrt{ }$ \\
\hline & Kerahasiaan & $\sqrt{ }$ & \\
\hline & Terhindar dari Riba & & $\sqrt{ }$ \\
\hline & Terhindar dari israf & $\sqrt{ }$ & \\
\hline & Terhindar dari gharar & & $\sqrt{ }$ \\
\hline & Terhindar dari risywah & & $\sqrt{ }$ \\
\hline & Terhindar dari tadlis & $\sqrt{ }$ & \\
\hline \multicolumn{2}{|l|}{ Jumlah } & 4 & 8 \\
\hline \multicolumn{2}{|c|}{ Prosentase Kehalalan } & $33 \%$ & $67 \%$ \\
\hline
\end{tabular}

Tabel 3

Contoh Mengukur Tingkat Kehalalan Produk

\begin{tabular}{|c|c|c|c|}
\hline \multirow[b]{2}{*}{ Nama Product } & \multirow[b]{2}{*}{ Aspek kehalalan } & \multicolumn{2}{|c|}{ Kehalalan } \\
\hline & & Terpenuhi & $\begin{array}{c}\text { Tidak } \\
\text { Terpenuhi }\end{array}$ \\
\hline \multirow{12}{*}{$\begin{array}{l}\text { Peminjaman } \\
\text { (Lending) (PT } \\
\text { Diam Saja) }\end{array}$} & Akuntabilitas & & $\sqrt{ }$ \\
\hline & Adil dalam Bertransaksi & & $\sqrt{ }$ \\
\hline & Transparansi Informasi & $\sqrt{ }$ & \\
\hline & Kewajaran & $\sqrt{ }$ & \\
\hline & Kesetaraan & $\sqrt{ }$ & \\
\hline & Kesalehan Sosial & & $\checkmark$ \\
\hline & Kerahasiaan & $\sqrt{ }$ & \\
\hline & Terhindar dari Riba & & $\sqrt{ }$ \\
\hline & Terhindar dari israf & $\sqrt{ }$ & \\
\hline & Terhindar dari gharar & & $\checkmark$ \\
\hline & Terhindar dari risywah & & $\sqrt{ }$ \\
\hline & Terhindar dari tadlis & $\sqrt{ }$ & \\
\hline \multicolumn{2}{|l|}{ Jumlah } & 6 & 6 \\
\hline \multicolumn{2}{|c|}{ Prosentase Kehalalan } & $50 \%$ & $50 \%$ \\
\hline
\end{tabular}


Berdasarkan table 1 sebagai contoh pengukuran kehalalan terhadap produk Payment Gateway maka nilai kehalalan lebih dominan daripada keharamannya. Sedangkanpada table 2 sebagai contoh pengukuran kehalalan terhadap produk Peminjaman (Lending) maka nilai keharamannya lebih dominan daripada kehalalannya. Sedangkan pada table 3 sebagai contoh pengukuran kehalalan terhadap produk Peminjaman (Lending) maka nilai kehalalannya sama dengan keharamannya. Bisa jadi produknya sama, tetapi yang melaksanakan perusahaan bisnis yang berbeda, maka nilai kehalalannya pun akan berbeda pula, karena ukuran kehalalan itu memiliki banyak variable yang satu perusahaan bisa memenuhi sedangkan perusahaan lain tidak bisa memenuhi.

Berdasarkan dalil-dalil dan contoh table pengukuran kehalalan diatas, masyarakat dapat lebih selektif dalam bermuamalah dan tidak terjebak dalam syariah label, akan tetapi bermuamalah dengan muamalah "label" dan "hakikat" syariah. Begitu juga ketika memilih fintech itu syariah dalam label atau syariah dalam hakikat, menyadari bahwa kehalalan fintech bisa memiliki kadar, tergantung seberapa besar aspek-aspek kesyariahan terpenuhi dalam bermuamalah.

\section{Penutup}

Kadar kehalalan fintech sangat dipengaruhi oleh seberapa besar terpenuhinya aspek-aspek kehalalannya dan seberapa kecil kadar aspek-aspek keharamannya, seperti Payment Gateway, Dompet Digital (Digital Wallet), Manajemen Kekayaan (Wealth Management), Pembiayaan Sosial (Social Crowdfunding), Peminjaman (Lending) halal dari sisi terotitik, tetapi bisa haram dari sisi praktik karena aspek kehalalannya tidak terpenuhi. Sebuah produk fintech Syariah bisa juga halal dari sisi teoritis akan tetapi bernilai subhat ketika aspek kehalalan dan keharamannya sama. Begitu juga produknya halal, tetapi dijalankan oleh perusahaan yang berbeda, maka kehalalannya bisa berbeda pula tergantung dari aspek apa yang terpenuhi dari sisi kehalalannya.

Masyarakat sering terjebak dalam produk yang berlabel syariah tanpa melihat aspek operasionalnya. Tidaklah salah melihat sebuah prodak muamalah berlabel Syariah adalah halal, namun ada yang lebih penting dari narasi syariah yakni hakikat Syariah sendiri, yakni bahwa sebuah perbuatan muamalah wajib terhindar dari transaksi yang ribawi, maysir, gharar, risywah, tadlis, israf, kehalalan. Namun, dalam transaksi fintech nilai kesyariahan juga harus memperhatikan aspek akuntabilitas, Adil dalam bertransaksi, transparasi informasi, Kewajaran, Kesetaraan, Kesalehan sosial agar kadar kesyariahan/kehalalan lebih tinggi. Jadi kesyariahan itu memiliki kadar yang berbeda-beda tergantung seberapa besar terpenuhi unsur syari'nya.

Literasi tentang Syariah perlu ditingkatkan untuk menghidari perilaku masyarakat yang sering mengambil keuntungan pribadi maupun kelompok, dari ketidakfahaman makna syariah. Bahwa umat muslim dengan cepatnya perkembangan teknologi tidak dapat menjastifikasi kesyariahannya sebelum melihat proses operasionalannya. Hukum fintech sangat fluktuatif berkenaan dengan manfaat dan kemadorotan yang ditimbulkan dari proses tersebut.

\section{DAFTAR PUSTAKA}

'Abas, Abi Hasan 'Alaudin bin Muhammad. al-Qawā̄id wa al-Fawā̄id al-Ușūliyah. Bairut: Maktabah al'Așriyah, 2002. 
Aaker, D. Building Strong Brands. Jakarta: Bumi Aksara, 2014.

Al-Ḥurāsān, Ișām Fāris. Tafsir al-Ṭabarī; Jaami al-Bayān an Ta'wül Ayyi al-Qur'ān. Bairut: Muasasah alRisālah, 1994.

Al-Zarqa, Ahmad bin Muhammad. Syarah Qawā’id al-Fiqhiyah. Damaskus: Darul Qalam, 2001.

Al-Salusi, Ali Ahmad. Mawsūuah al-Qadāyā al-Fiqhiyah al-Mu'ạsirah wa al-Iqtisād al-Islāmī. Mesir: Maktabah Darul Quran, 2004.

Amalia, Fitri. "Book Review : The Fintech Book : The Financial Technology Handbook for Investor, Enterpreneurs and Visionaries." Journal of Indonesia Economic and Business Volume 31 (2016): Pages 346.

Calopa, Marina Klackmer, Jelena Horvat, and Maja Lalic. "Analysis of Financing Sources For Start-Up Companies." Management Journal Volume 19 (2014): Pages 19-44.

Drnovsek, Wincent, and Cardon. "The Nature and Experience of Enterpreneurial Passion," 2010, Pages 56.

Hidayati, Suryanti, A Firmansyah, A Fadly, and I.Y. Darmawan. "Kajian Operasional E-Money.” Bank Indonesia, 2006.

Muhammad ibn Imsā’il al-Bukharī. Al-Jāmi’ al-Musnad al-Șaḥịh al-Mukhtașar min Umūr Rasulullah Șallallah 'alaihi Wasallam wa Sunnanih wa Ayyamih. Edited by Muhammad Zāhir bin Nāṣir. Bairūt: Dār al-Ṭūq al-Najāh, 1422.

Niazi, Liaquat Ali Khan. Islamic Law Contract. Pakistan, research cell, Dyal sing trust Library Nisbet Road lahore, 1990.

Ompian, M.M. Behavioral Finance and Wealth Management. Hoboken, New Jersey: John Wiley \& Sons Inc, 2006.

Otoritas Jasa Keuangan. Statistik Perbankan Syariah, 2015.

---. Statistik Perbankan Syariah, 2017.

---. Statistik Perbankan Syariah, 2019.

Pramono, Nindyo. "Revolusi Dunia Bisnis Indonesia Melalui E-Commerce Dan E-Business: Bagaimana Solusi Hukumnya.” Hukum Volume 8 (2001): Pages 16-28.

Romanova, I, and M Kudinska. Contemporarry Issues in Finance: Banking and FinTech: A Challenge or Opportunity? London: Emerald group Publishing Limited, 2016.

Rusdyana, Aam Slamet. "Bagaimana Pengembangan Industri Fintech Syariah Di Indonesia? Pendekatan Interpretive Structural Model.” al-Muzara'ah Volume 62 (2018): Pages 123.

Shihab, M.Quraish. Tafsir Al-Misbah: Pesan, Kesan Dan Keserasian Al-Quran. Jakarta: Lentera Hati, 2002.

Wibowo, Budi. Analisa Regulasi Fintech Dalam Membangun Perekonomian Di Indonesia. Jakarta, Indonesia, 2013. 